\title{
A comparison of spatial and temporal patterns in epiphytic macroalgal assemblages of the seagrasses Amphibolis griffithii and Posidonia coriacea
}

\author{
P. S. Lavery ${ }^{*}$, M. A. Vanderklift ${ }^{* *}$ \\ Centre for Ecosystem Management and School of Natural Sciences, Edith Cowan University, 100 Joondalup Drive, \\ Joondalup, Western Australia 6027, Australia
}

\begin{abstract}
Studies of patterns in assemblages of epiphytic macroalgae growing on seagrasses have largely focussed at the scale of leaves or shoots. Few have examined patterns at larger spatial scales or the influence of host seagrass type on these patterns, despite interest in monitoring changes in epiphyte composition that can lead to the death of seagrasses. We studied spatial patterns in assemblages of epiphytic macroalgae on 2 seagrass species with different morphologies and longevity, Amphibolis griffithii and Posidonia coriacea, which co-occur on Success Bank, Western Australia. Epiphyte assemblages were described for each species at a hierarchy of spatial scales (sites separated by 10s, 100s and 1000s m) in summer and winter. At all locations and at both times, A. griffithii supported a higher species richness. A total of 91 taxa were recorded on A. griffithii and 70 on $P$. coriacea. Both seagrass species showed strong temporal patterns in their epiphyte macroalgal assemblages, but this was stronger in $P$. coriacea. For A. griffithii spatial variation was the dominant pattern. Epiphyte assemblages of the 2 seagrasses displayed striking differences in patterns of dissimilarity at different spatial scales. For A. griffithii, Bray-Curtis dissimilarity (D) among pairs of samples progressively increased with increasing spatial scale $(\mathrm{D}=0.31,0.37$ and 0.47 at scales of 10s, 100s and 1000s m, respectively). For P. coriacea, the differences among samples separated by $10 \mathrm{~s} \mathrm{~m}$ or $100 \mathrm{~s} \mathrm{~m}$ were relatively small $(0.29$ and 0.32 , respectively), but the differences among samples $1000 \mathrm{~s} \mathrm{~m}$ apart were much greater (0.52). We suggest that the differences in spatial and temporal patterns between species of seagrass may reflect an interaction of timescales of seagrass longevity with timescales of algal reproductive biology and the dispersal ranges of algal propagules. Due to the high turnover of $P$. coriacea leaves, the assemblages present at any given time are strongly influenced by recent recruitment events. The epiphytic assemblage of long-lived A. griffithii integrates a much longer period of recruitment, so that recent events may produce comparatively smaller shifts in composition. The longevity of A. griffithii may also permit local reinforcement of existing assemblages, so that differences in assemblage structure increase with spatial scale. The high turnover of $P$. coriacea leaves results in less opportunity for an assemblage to reinforce its presence, so patterns at the smaller scales are comparatively weaker. Strong patterns across $\mathrm{km}$ are more likely to be the result of environmental gradients. Patchiness within these gradients leads to complex, many layered spatial patterns.
\end{abstract}

KEY WORDS: Seagrass $\cdot$ Macroalgae $\cdot$ Epiphytes $\cdot$ Diversity $\cdot$ Spatial patterns $\cdot$ Australia Resale or republication not permitted without written consent of the publisher

\section{INTRODUCTION}

*E-mail: p.lavery@cowan.edu.au

** Present address: Botany Department, The University of Western Australia, Nedlands, Western Australia 6907, Australia
Epiphytic algae (diatoms, cyanobacteria and true multicellular algae) are a diverse and often specialised 
flora growing on host macrophytes. Their importance to seagrass ecosystem functioning in terms of primary production and food supply for grazers and detritivores is well-recognised (Penhale 1977, Morgan \& Kitting 1984, Moncreiff et al. 1992). They have also been implicated in the death of seagrasses, as a direct result of nutrient enrichment causing an increase in epiphytic algal biomass, which in turn reduces light availability at the seagrass leaf surface (Sand-Jensen 1977, Cambridge et al. 1986, Silberstein et al. 1986, Frankovich \& Fourqurean 1997).

Associated with increases in epiphytic algal biomass is an alteration in species composition and structural form of the epiphyte assemblage (Coleman \& Burkholder 1994, Cebrián et al. 1999). Such changes in epiphyte assemblages may well reflect changes in the functioning of a seagrass ecosystem, and could serve as an early warning signal of eutrophication. However, detecting a change that managers can attribute to anthropogenic impacts (such as nutrient enrichment) requires an ability to differentiate anthropogenic-driven changes from natural spatial and temporal patterns.

Unfortunately, good quantitative data describing both spatial and temporal patterns in unimpacted assemblages of epiphytic macroalgae are few. While there is a history of research examining spatial patterns in the composition of epiphytic macroalgae, most studies have focussed on small spatial scales, within or among leaves (Bulthuis \& Woelkerling 1983, Jacobs et al. 1983, Cullinane et al. 1985, Lethbridge et al. 1988, Borowitzka et al. 1990, Reyes \& Sansón 1997, Cebrián et al. 1999). At larger scales, natural changes in species composition over spatial scales may be broadly correlated with environmental gradients such as depth (Jacobs 1983, Cinelli et al. 1984, Buia et al. 1989), salinity (Kendrick et al. 1988) and wave energy (Kendrick \& Burt 1997, Pinckney \& Micheli 1998). The consistency of spatial differences over time has received little attention (however see Kendrick \& Burt 1997).

A further potentially important source of variation is the availability of suitable hosts. Variation in epiphyte species composition among morphologically different hosts has been recorded for macroalgae (Ballantine 1979, Arrontes 1990) and seagrasses (May \& Collins 1978, Jernakoff \& Neilsen 1998), although Heijs (1987) found little difference in the compositions of epiphytic macroalgae growing on different seagrasses in a mixed meadow. Potentially, differences among seagrass hosts may be as great as those caused by environmental gradients, and there is no evidence that the epiphyte assemblage on each host will follow the same spatial and temporal patterns. If the epiphyte assemblages on different hosts do indeed have different spatial and temporal patterns, this may also affect our ability to detect impacts of human activity.
The aim of this study was to examine the variability in the composition of epiphytic macroalgal assemblages at a range of spatial scales, through time and between 2 morphologically distinct seagrass hosts: Amphibolis griffithii (J. Black) den Hartog (Cymodoceae) and Posidonia coriacea Kuo \& Cambridge (Posidoniaceae). A. griffithii has lignified stems, which persist for about $700 \mathrm{~d}$ (Coupland 1997), and terminal leaf clusters, which persist for 5 to 80 d (G. A. Kendrick pers. comm.). The stems support the bulk of the epiphytic biomass. The plant occurs in locations ranging from highly sheltered to exposed, and tends to form meadows with continuous cover at spatial scales of 100 s of $\mathrm{m}^{2}$. In contrast, $P$. coriacea has a horizontal rhizome belowground bearing upright, strap-like leaves that are shed every 35 to 128 d (Lavery et al. 1999). It tends to occur in more exposed locations, where it forms patchy meadows interspersed with sand. Both species co-occur in some areas of southern Australia and can form mixed meadows. It has previously been suggested that interactions between seagrass longevity and the reproductive biology of algal epiphytes could account for between-site differences in epiphyte assemblages (Jacobs et al. 1983, Kendrick \& Burt 1997, Reyes \& Sansón 1997). The co-occurrence of 2 seagrasses with significantly different longevity provided the opportunity to explore this hypothesis further. In this study, we tested whether patterns in spatial and temporal variation of assemblages of epiphytic macroalgae were similar for $A$. griffithii and $P$. coriacea. Specifically, we tested whether the species richness and composition of macroalgae, and the spatial and temporal patterns in dissimilarity of assemblages differed between the 2 seagrass habitats.

\section{MATERIALS AND METHODS}

Study area. Success Bank, Western Australia (Fig. 1), is a relatively shallow bank $(<10 \mathrm{~m})$, composed mainly of calcium carbonate sediments. It contains patches of bare sand and seagrass with Amphibolis griffithii and Posidonia coriacea the dominant canopy-forming seagrass species (Kendrick et al. 1999). These occur as pure and mixed stands, usually with several understory species, such as Heterozostera tasmanica (Martens ex Aschers.) and Syringodium isoetifolium (Aschers.) Dandy.

As we wished to examine changes in species composition of epiphyte assemblages across Success Bank, we sampled in 3 regions (east, north and west regions; Fig. 1). These encompassed a large enough geographic scale to address our questions and include variability in wave energy and proximity to riverine influences, factors considered likely to influence macroalgal assemblage 
composition (Table 1). Region-specific nutrient data are not available, but Cary et al. (1995) report mean winter nutrient concentrations at the mouth of the Swan River and in Owen Anchorage, which approximate a NE-SW transect through our study region. Nitrate, ammonium and filterable reactive phosphate (FRP) concentrations were higher near the Swan River (163, 28 and $23 \mu \mathrm{g} \mathrm{l}^{-1}$, respectively) and lower at Owen Anchorage (11, 1 and $2 \mu \mathrm{g} \mathrm{l^{-1 }}$, respectively), indicating a gradient in nutrient concentrations across the study area. All sites were located more than $5 \mathrm{~km}$ from reef systems and lacked hard substrate which could support macroalgal assemblages that could act as a source of algal propagules. Within each region, we selected 2 sites for both Amphibolis griffithii and Posidonia coriacea. The first site was randomly located within the appropriate seagrass habitat, the second was haphazardly located within a few $100 \mathrm{~m}$ of the first to ensure the appropriate spatial scale was established. Different regions were separated by 1.8 to $2.4 \mathrm{~km}$ for $A$. griffithii, and by 1.2 to $3.1 \mathrm{~km}$ for $P$. coriacea. Within each region, the sites were separated by 100 to $230 \mathrm{~m}$ for both species. Typically both species occurred within any given site, though separated by 10 s to 100 s m. We sampled each site twice: once during summer (February), and once during the winter (August) of 1997. On each occasion sampling was completed over $2 \mathrm{~d}$.

Sample collection. During each sampling period, we collected 6 replicate, randomly located samples of each seagrass at each site. Each sample was collected from a $100 \mathrm{~cm}^{2}$ quadrat. All shoots within the quadrat (generally 2 to 4 for Amphibolis griffithii and 6 to 8 for Posidonia coriacea) were collected, and as much belowground material as possible was collected to ensure

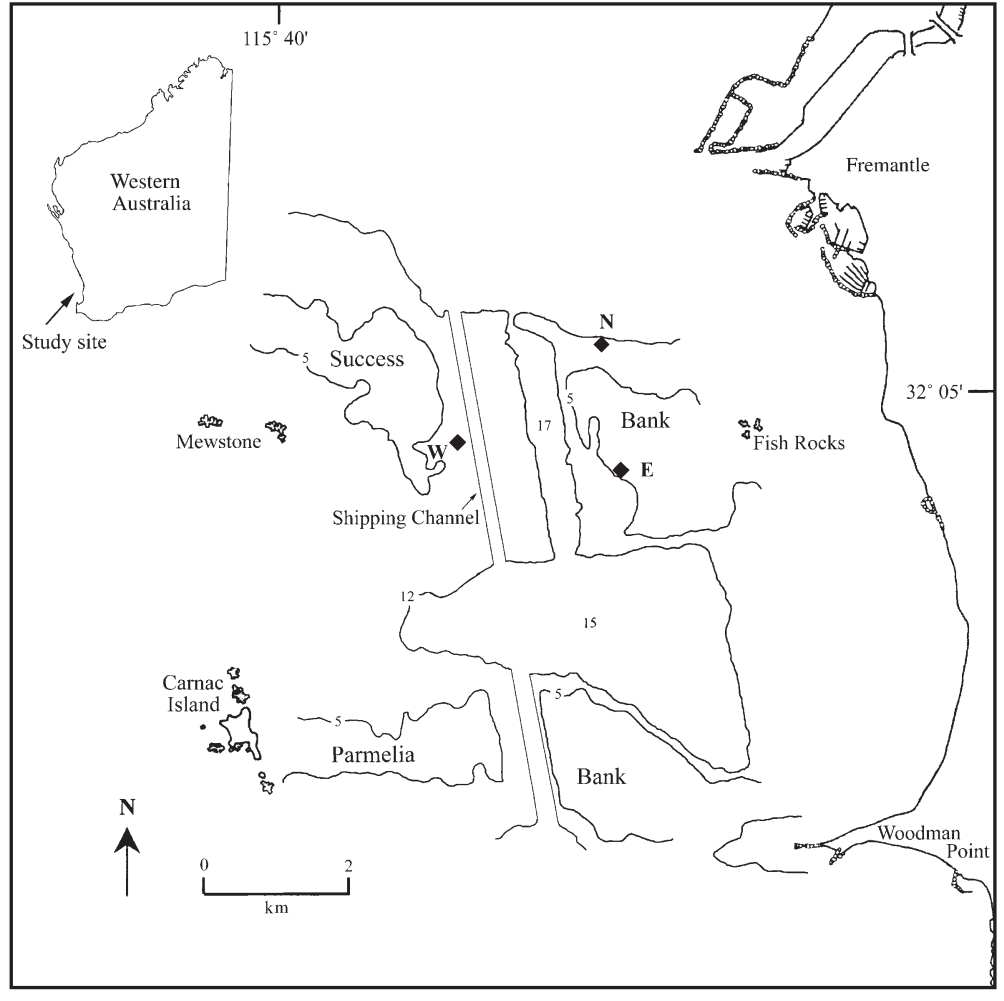

Fig. 1. Map of Success Bank, Western Australia, showing the 3 sampling regions $(\mathrm{E}=$ east, $\mathrm{N}=$ north and $\mathrm{W}=$ west $)$. Both Amphibolis griffithii and Posidonia coriacea were sampled at 2 sites (separated by $100 \mathrm{~s} \mathrm{~m}$ ) within each region. $5 \mathrm{~m}$ isobaths are indicated. Small numerals indicate spot depths $(\mathrm{m})$ in basin and channel areas

that shoots remained intact. Samples were bagged in seawater with $5 \%$ formalin and transferred to the laboratory. In the laboratory, all leaves and stems of each shoot were examined using a dissecting microscope at $10 \times$ objective magnification. The presence, but not the precise location, of each epiphytic macroalgal taxon (true multicellular macroalgae and cyanobacteria) on a shoot was recorded. Where possible taxa were identified to species level: in some cases it was not possible

Table 1. Comparison of environmental characteristics at each of the study regions

\begin{tabular}{|c|c|c|c|c|}
\hline Variable & East & $\begin{array}{l}\text { Region } \\
\text { North }\end{array}$ & West & Source \\
\hline Depth (m) & $5-7$ & $5-7$ & $5-7$ & \\
\hline Proximity to mainland $(\mathrm{km})$ & 3.89 & 4.00 & 6.10 & \\
\hline Proximity to Swan River (km) & 4.42 & 3.16 & 5.47 & \\
\hline Salinity & 33.75 & 33.50 & 34.75 & D'Adamo et al. (1995) \\
\hline Chl a $\left(\mu \mathrm{gl}^{-1}\right)$ & 0.87 & & 0.76 & Burt et al. (1995) \\
\hline Mean light attenuation coefficient $\left(\mathrm{m}^{-1}\right)$ & 0.094 & & 0.079 & Burt et al. (1995) \\
\hline Significant wave height in westerly storm (m) & 1.75 & 2.10 & 1.25 & Rogers (1997) \\
\hline Significant wave height in northwesterly storm (m) & 1.5 & 1.75 & 1.25 & Rogers (1997) \\
\hline Bottom orbital velocity in westerly storm $\left(\mathrm{cm} \mathrm{s}^{-1}\right)$ & $20-50$ & $50-100$ & $10-20$ & Rogers (1996) \\
\hline Bottom orbital velocity in northwesterly storm $\left(\mathrm{cm} \mathrm{s}^{-1}\right)$ & $10-20$ & $50-100$ & $20-50$ & Rogers (1996) \\
\hline
\end{tabular}




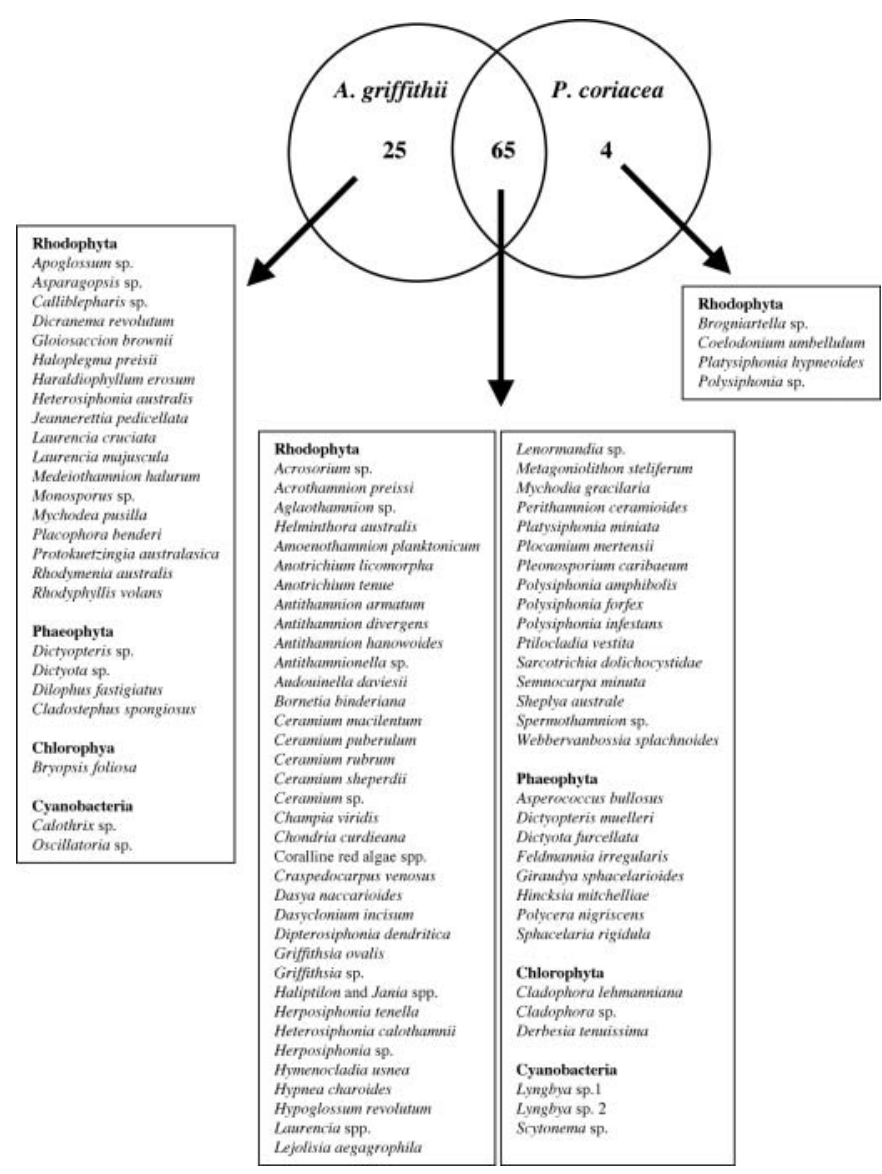

Fig. 2. Venn diagram showing the distribution of macroalgal epiphyte taxa on Amphibolis griffithii and Posidonia coriacea. The number of taxa either unique to 1 seagrass or recorded on both are shown

to discern between juveniles of several species, and they were combined. We then used the data to calculate the proportion of shoots in a quadrat on which each taxon occurred.
Statistical analyses. Species richness: Spatial and temporal patterns in species richness were analysed by 4 -factor analysis of variance (ANOVA). Data were first tested for homogeneity of variances using Cochran's test, and were transformed as appropriate if variances were heterogeneous. Seagrass was treated as a fixed factor, while other factors (regions, sites nested within regions and sampling periods) were treated as random.

Multivariate patterns: We examined spatial and temporal patterns in the multispecies data using several different multivariate statistical methods. We used semi-strong hybrid multidimensional scaling (SSH: Belbin 1991) in the PATN software package (Belbin 1993) to construct ordinations of all quadrats based on Bray \& Curtis dissimilarity values (Bray \& Curtis 1957) calculated from untransformed proportion data. Ordinations were constructed in 2 dimensions, using an ordinal approach for dissimilarities above zero.

We assessed the ability of the ordinations to represent patterns contained in the underlying dissimilarities by examining the stress values. As stress values will vary according to the number of objects (samples) and attributes (species) in the original data (Vanderklift et al. 1996), we did this by Monte Carlo randomisation tests. Data sets were subjected to Monte Carlo reordering to create 1000 randomised data sets. We conducted SSH ordinations for each, and compared the stress values thus generated with those yielded by the original data.

To examine the significance of patterns in species composition between sites, among regions and between sampling periods, we conducted analysis of similarities (ANOSIM) based on Bray \& Curtis similarity values calculated from untransformed proportion data, using the PRIMER software package (Carr 1997). Two sets of ANOSIM tests were conducted. First, we conducted 2-way nested ANOSIM (Clarke 1993) separately for each seagrass-sampling period combination;

Table 2. Results of 4-factor ANOVA on square root-transformed species richness. -: no exact $F$-test. The column ' $F$ versus' indicates the denominator MS used in the model. * Statistically significant result

\begin{tabular}{|c|c|c|c|c|c|}
\hline Source of variation & df & MS & $F$ versus & $F$ ratio & $\mathrm{p}$ \\
\hline Seagrass (S) & 1 & 125.99 & No test & - & - \\
\hline Region (R) & 2 & 11.66 & No test & - & - \\
\hline $\mathrm{S} \times \mathrm{R}$ & 2 & 0.55 & No test & - & - \\
\hline Sites $(\mathrm{S} \times \mathrm{R}) \mathrm{Si}(\mathrm{S} \times \mathrm{R})$ & 6 & 0.17 & $\mathrm{Si}(\mathrm{S} \times \mathrm{R}) \times \mathrm{T}$ & 0.31 & 0.913 \\
\hline Sampling period $(\mathrm{P})$ & 1 & 1.47 & $\mathrm{Si}(\mathrm{S} \times \mathrm{R}) \times \mathrm{T}$ & 2.63 & 0.156 \\
\hline $\mathrm{S} \times \mathrm{P}$ & 1 & 2.70 & $\mathrm{~S} \times \mathrm{R} \times \mathrm{T}$ & 4.89 & 0.158 \\
\hline $\mathrm{R} \times \mathrm{P}$ & 2 & 1.12 & Residual & 3.08 & $0.050^{*}$ \\
\hline $\mathrm{S} \times \mathrm{R} \times \mathrm{P}$ & 2 & 0.55 & Residual & 1.51 & 0.224 \\
\hline $\mathrm{Si}(\mathrm{S} \times \mathrm{R}) \times \mathrm{P}$ & 6 & 0.56 & Residual & 1.53 & 0.173 \\
\hline Residual & 120 & 0.36 & & & \\
\hline
\end{tabular}


this was to test for differences among regions and between sites within each region. Then, we pooled sites to conduct 2-way crossed ANOSIM (Warwick et al. 1990) separately for each seagrass, testing for differences among regions and between sampling periods.

Species analysis: To examine the epiphytic macroalgal taxa that contributed most strongly to dissimilarities between samples from different regions and/or sampling periods, we used the SIMPER method described by Clarke (1993). We employed the average contribution of each taxon to the overall dissimilarity between sets of samples $\bar{\delta}_{\mathrm{i}}$, and the standard deviation of this contribution $\operatorname{SD}\left(\bar{\delta}_{\mathrm{i}}\right)$. We used the ratio of mean to SD as a statistic $\bar{\delta}_{\mathrm{i}} / \mathrm{SD}\left(\bar{\delta}_{\mathrm{i}}\right)$ to evaluate the contribution of each taxa to the dissimilarity between pairs of samples. We used as an arbitrarily defined cut-off point a mean to $\mathrm{SD}$ ratio of 2 , so that the mean contribution was higher than the variation.

Because SIMPER is essentially a 1-way test, we could not use it to estimate the variability at each level of the spatial hierarchy, information that was of particular interest. For this, we used nested ANOVA to test, for each species, the important scales of variance (i.e. was there significant spatial variability at the scales of region, site nested within region, or both). Separate nested ANOVA analysis for each seagrass-time combination was performed because the full 4 -factor model did not yield an exact $F$-test for the region level. Data were tested for homogeneity of variances using Cochran's test and if they met the criteria, the analysis was performed on raw data. Where data failed Cochran's test, arcsine transformations were applied prior to analysis. If the data still failed Cochran's test, they were omitted from analysis because of the likelihood of biasing results toward significant site-level effects.

\section{RESULTS}

\section{Species richness}

More taxa were recorded on Amphibolis griffithii (91) than on Posidonia coriacea (70) (Fig. 2). In each region, and during both sampling periods, A. griffithii had higher species richness. The majority of taxa (66) were present on both A. griffithii and P. coriacea, but A. griffithii was host to a large number of taxa (25) that did not occur on $P$. coriacea. Only 4 species occurred solely on $P$. coriacea.

Differences in species richness could not be tested for seagrass, region or the seagrass $\times$ region interaction because of the lack of an exact $F$-test for these factors in the full 4-factor ANOVA model (Table 2). We did not pool interaction terms as $p<0.25$ for the lowest level of
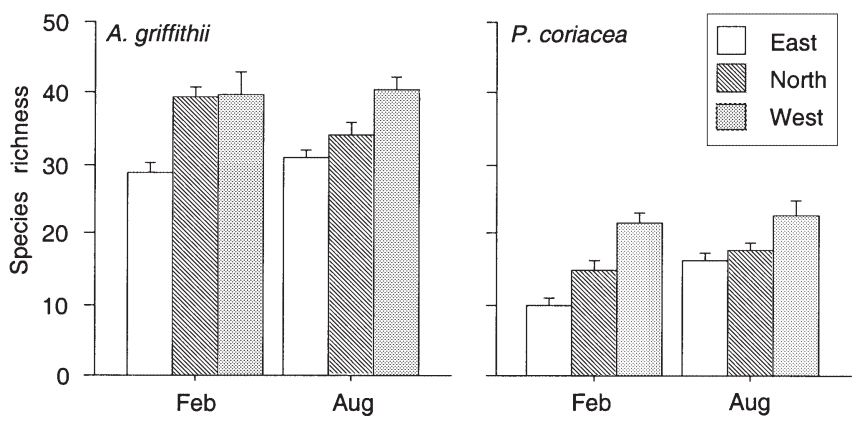

Fig. 3. Mean species richness $( \pm \mathrm{SE})$ of macroalgal epiphytes on Amphibolis griffithii and Posidonia coriacea in each study region in both sampling periods

the analysis. Examination of the mean squares for seagrass suggests that this contributed the majority of variability. There was a significant region $\times$ sampling period interaction ( $p=0.05$; Table 2$)$, which seemed to be a result of differences in species richness between February and August in the north A. griffithii sites and the east $P$. coriacea sites (Fig. 3).

\section{Ordination}

The ordination of all 144 quadrats (i.e. all replicate quadrats from all sites in all regions on both dates) showed variable patterns and yielded stress values considerably lower than those produced by randomised data (Figs. 4 \& 5). Symbols in Fig. 4 depict patterns associated with seagrass type and sampling period, as these were the 2 dominant patterns in this ordination. The plot clearly shows the separation of Amphibolis griffithii assemblages from Posidonia cori-
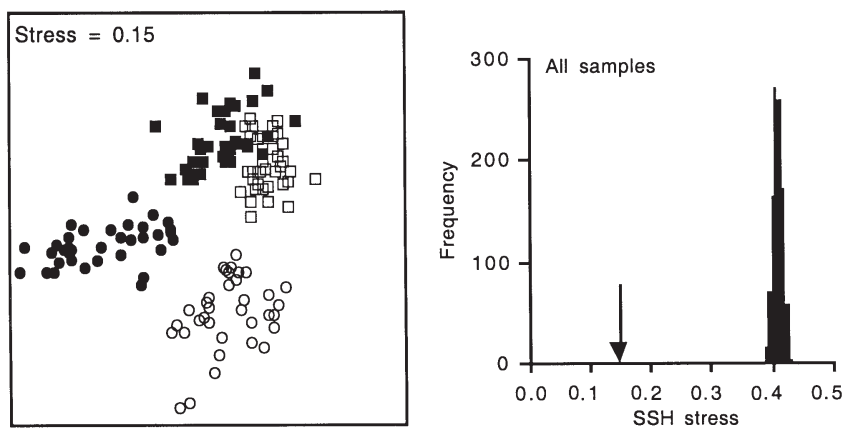

Fig. 4. Semi-strong hybrid multidimensional scaling ordination of all samples from Amphibolis griffithii (घ, February; $\square$, August) and Posidonia coriacea (•, February; o, August). The ordination was constructed in 2 dimensions using untransformed data. The histograms on the right indicate the stress value of each plot (arrow) in relation to the stress values of ordinations produced by re-sorting the original data in 1000 random permutations 
A

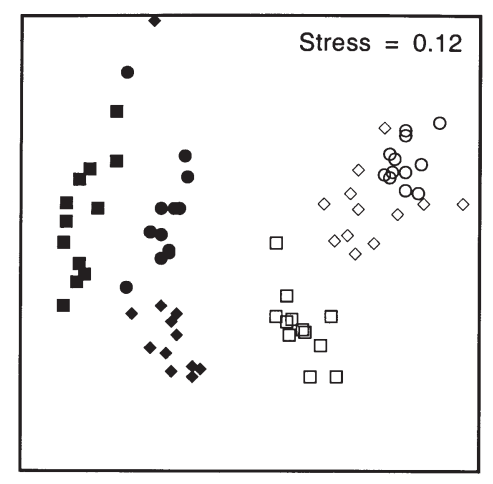

B

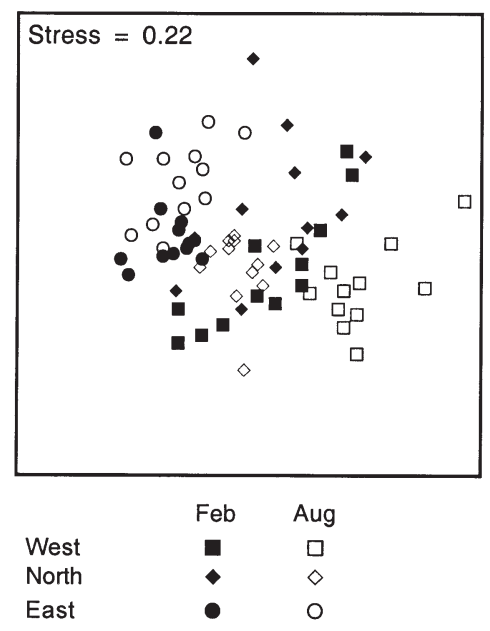

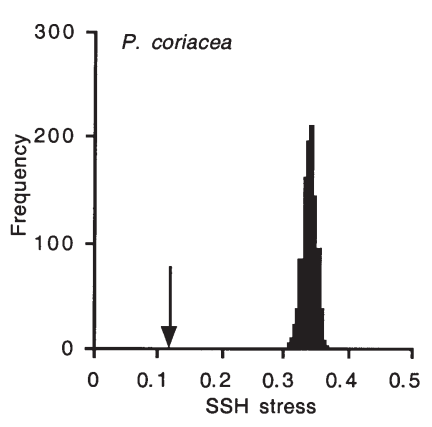

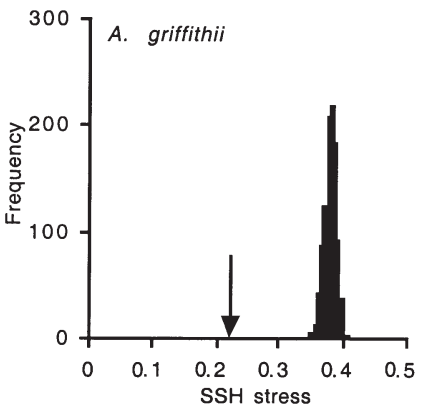

Fig. 5. Semi-strong hybrid multi-dimensional scaling ordinations, constructed in 2 dimensions using untransformed data: (A) all samples collected from Posidonia coriacea, (B) all samples collected from Amphibolis griffithii. The histograms on the right indicate the stress value of each plot (arrow) in relation to the stress values of ordinations produced by re-sorting the original data in 1000 random permutations

Table 3. Results of 2-way nested ANOSIM tests examining differences among regions and between sites within regions, using untransformed proportion data. ${ }^{*}$ Statistically significant result

\begin{tabular}{|llccc|}
\hline $\begin{array}{l}\text { Seagrass } \\
\text { Sampling period }\end{array}$ & Variable & $\begin{array}{c}\text { Clarke's } \\
R \text {-values }\end{array}$ & $\begin{array}{c}\text { No. of } \\
\text { permutations }\end{array}$ & $\begin{array}{c}\text { Significance } \\
(\%)\end{array}$ \\
\hline $\begin{array}{l}\text { Amphibolis griffithii } \\
\text { Feb }\end{array}$ & & & & \\
& Region & 0.889 & 15 & 6.7 \\
Aug & Site (Region) & 0.562 & 5000 & $0.0^{*}$ \\
& Region & 0.500 & 15 & 26.7 \\
Posidonia coriacea & Site (Region) & 0.416 & 5000 & $0.0^{*}$ \\
Feb & Region & 1.000 & 15 & 6.7 \\
& Site (Region) & 0.135 & 5000 & $1.4^{*}$ \\
Aug & Region & 1.000 & 15 & 6.7 \\
& Site (Region) & 0.171 & 5000 & $0.8^{*}$ \\
\hline
\end{tabular}

acea assemblages, indicating substantial differences in species composition. Within each seagrass type, there is also some separation of the February and August samples, a pattern particularly evident for samples collected from P. coriacea. The low stress value for the original data (0.15) indicates that the ordination was a good representation of the underlying dissimilarity values.

To examine the spatial patterns more clearly, separate ordinations were constructed for each seagrass type (Fig. 5). For Posidonia coriacea, this again yielded strong patterns related to sampling period, but also indicated that there were differences among regions within each sampling period (Fig. 5A). In the ordination of Amphibolis griffithii quadrats separation of assemblages from different regions was the dominant pattern rather than separation according to sampling period (Fig. 5B). While samples clustered clearly for both seagrass ecosystems, the separation was, visually, stronger for P. coriacea.

\section{ANOSIM}

The ANOSIM tests conducted to examine spatial differences within each combination of seagrass and sampling period generally showed similar results (Table 3). For each test, there were significant differences between sites within regions. Regions, despite having very high Clarke's $R$-values (indicating strong discrimination among regions) were not significantly different, due to the low number of permutations possible. Posidonia coriacea yielded the highest Clarke's $R$-values for the region factor, while Amphibolis griffithii yielded the highest Clarke's $R$-values for the site factor. This indicates that differences at the $\mathrm{km}$ scale were most pronounced for $P$. coriacea, but differences at the scale of 100 to $200 \mathrm{~m}$ were also large for A. griffithii.

We then pooled sites to enable more powerful testing of differences between regions, and also allowing us to include sampling period in the analyses. The subsequent 2-way crossed ANOSIM revealed highly significant differences in assemblages associated with regions and sampling period (Table 4). Pairwise comparisons of regions showed that the epiphyte assemblages of each region were sig- 
nificantly different from the others for both seagrass types (Table 5). Posidonia coriacea yielded the highest Clarke's $R$-values for region, time of sampling and each pairwise comparison (Tables 4 \& 5), indicating very strong discrimination among assemblages, and reflecting the patterns evident in the ordinations (Figs. 4 \& 5).

Plots of the mean dissimilarity at each of the 3 spatial scales sampled highlighted that while both seagrass ecosystems displayed strong spatial patterns in assemblages, the strength of the patterns differed in a fundamental way between Amphibolis griffithii and Posidonia coriacea (Fig. 6). Mean dissimilarity among pairs of samples from the same site were similar for both seagrasses. For A. griffithii, the mean dissimilarity among pairs of quadrats progressively increased with increasing spatial scale. In contrast, for P. coriacea, the differences among quadrats collected from the same site or the same region were relatively small, but the differences among quadrats collected from different regions were quite large. In other words, increasing the distance among quadrats from $\mathrm{m}$ to $100 \mathrm{~s} \mathrm{~m}$ did not result in a substantial increase in dissimilarities; however, increasing the distance to $\mathrm{km}$ resulted in a substantial increase in dissimilarities.

\section{Characteristic taxa}

Numerous taxa were found only on Amphibolis griffithii, regardless of location or date of sampling (Fig. 2). Most taxa were found predominantly on A. griffithii, but were recorded on Posidonia coriacea either infrequently or in much lower proportions. Some, however, were never recorded on $P$. coriacea (e.g. Dicranema revolutum, Mychodea pusilla, Haloplegma preisii). In contrast, no taxa were were found on $P$. coriacea at all locations and on both dates of sampling.

The species of epiphytic macroalgae that contributed strongly to the dissimilarities among regions were different for Amphibolis griffithii and Posidonia coriacea (Table 6). Of the 22 species for which SIMPER yielded mean to SD ratios $>2$, only 2 (Chondria curdeiana and Lyngbya sp. 1) were significant contributors to the patterns in both $A$. griffithii and $P$. coriacea. For A. griffithii, the abundance of 5 species of epiphytic macroalgae discriminated strongly between regions in winter. Four of these species also contributed to the discrimi- nation between regions in summer, with a further 7 species also contributing. Spatial patterns in the abundance of species that contributed strongly to the discrimination among regions in both seasons were similar on both occasions: Metagoniolithon stelliferum, Laurencia spp. and Dictyota furcellata were most abundant in the west region, and Antithamnion armatum in the north. Only 2 species showed a significantly greater abundance in the east, Polysiphonia amphibo-

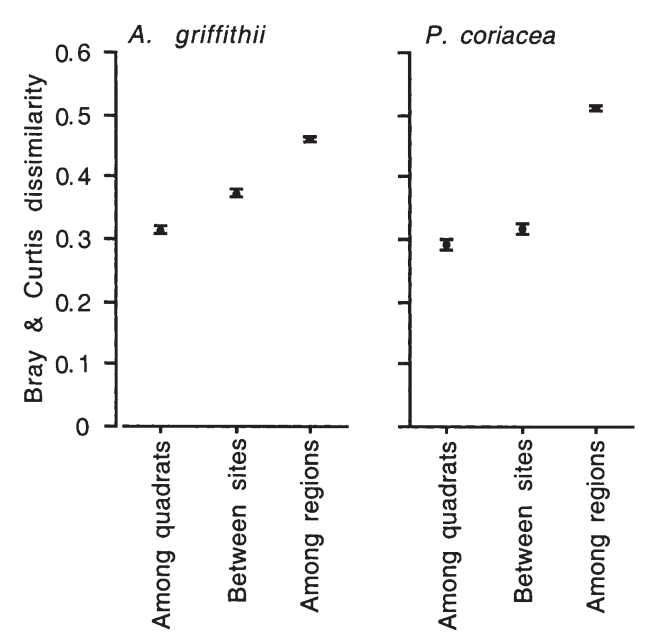

Fig. 6. Mean Bray \& Curtis dissimilarity of macroalgal epiphyte samples taken from Amphibolis griffithii and Posidonia coriacea at a hierarchy of spatial scales. Values are means \pm SD 
Table 6. The mean proportion of shoots supporting taxa revealed by SIMPER as important for discriminating among regions for each seagrass-time combination. Tables show species for which the mean-to-SD ratios are $>2 .{ }^{*}$ Value is significantly different $(p<0.05)$ to one of the other regions. ${ }^{* *}$ Value is significantly different $(p<0.05)$ to both of the other regions

\begin{tabular}{|c|c|c|c|}
\hline Seagrass & W & $\mathrm{N}$ & E \\
\hline \multicolumn{4}{|l|}{ Amphibolis griffithii } \\
\hline \multicolumn{4}{|l|}{ Aug } \\
\hline Aglaothamnion sp. 1 & & $0.60^{*}$ & $0.16^{*}$ \\
\hline Antithamnion armatum & $0.02^{*}$ & $0.57^{*}$ & \\
\hline Dictyota furcellata & $0.46^{*}$ & & $0.03^{*}$ \\
\hline Laurencia spp. & $0.44^{*}$ & & $0.00^{*}$ \\
\hline Metagoniolithon steliferum & $0.48^{* *}$ & $0.02^{*}$ & $0.00^{*}$ \\
\hline \multicolumn{4}{|l|}{ Feb } \\
\hline Acrothamnion priesii & $0.70^{*}$ & & $0.16^{*}$ \\
\hline Antithamnion armatum & $0.08^{*}$ & $0.77^{* *}$ & $0.07^{*}$ \\
\hline Audouinella daviesii & $0.03^{*}$ & $0.56^{*}$ & \\
\hline Chondria curdeiana & & $0.70^{*}$ & $0.10^{*}$ \\
\hline Dicranema revolutum & $0.66^{*}$ & $0.66^{*}$ & $0.03^{* *}$ \\
\hline Dictyota furcellata & $0.58^{*}$ & & $0.00^{*}$ \\
\hline Laurencia spp. & $0.57^{* *}$ & $0.02^{*}$ & $0.06^{*}$ \\
\hline Lyngbya sp. 1 & $0.29^{*}$ & & $0.83^{*}$ \\
\hline Metagoniolithon stelliferum & $0.37^{* *}$ & $0.02^{*}$ & $0.00^{*}$ \\
\hline Polysphonia amphibolis & $0.07^{*}$ & & $0.67^{*}$ \\
\hline Rhodophyllis volans & & $0.50^{*}$ & $0.00^{*}$ \\
\hline \multicolumn{4}{|l|}{ Posidonia coriacea } \\
\hline \multicolumn{4}{|l|}{ Aug } \\
\hline Ceramium puberulum & $0.17^{*}$ & $0.80^{*}$ & \\
\hline Ceramium rubrum & & $0.66^{*}$ & $0.20^{*}$ \\
\hline Giraudya sphacelarioides & $0.44^{*}$ & $0.01^{* *}$ & $0.74^{*}$ \\
\hline Hincksia mitchelliaea & $0.26^{*}$ & & $0.58^{*}$ \\
\hline Lenormandia sp. & $0.22^{* *}$ & $0.00^{*}$ & $0.00^{*}$ \\
\hline Polycerea nigrescens & $0.59^{*}$ & $0.00^{* *}$ & 0.54 \\
\hline \multicolumn{4}{|l|}{ Feb } \\
\hline Ceramium macilentum & $0.35^{*}$ & $0.55^{*}$ & \\
\hline Ceramium puberulum & $0.94^{* *}$ & $0.14^{*}$ & $0.05^{*}$ \\
\hline Chondria curdieana & $0.63^{* *}$ & $0.13^{*}$ & $0.01^{*}$ \\
\hline Haliptilon/Jania comb & $0.70^{* *}$ & $0.15^{*}$ & $0.02^{*}$ \\
\hline Lyngbya sp. 1 & $0.95^{*}$ & & $1.00^{*}$ \\
\hline Polysiphonia infestans & $0.14^{*}$ & $0.75^{*}$ & \\
\hline Scytonema sp. & $0.00^{*}$ & $0.09^{*}$ & $0.94^{* *}$ \\
\hline
\end{tabular}

lis and the cyanobacterium Lyngbya sp. 1, and this pattern only occurred in summer.

In contrast, species that strongly discriminated between regions for Posidonia coriacea were different in February and August (Table 6). In August, 6 species contributed strongly to this discrimination, with Giraudya sphacelarioides and Hinksia mitchelliae more abundant in the east, Ceramium rubrum and $C$. puberulum in the north, and Polycerea nigrescens and Lenormandia sp. in the west. In February, 2 species of cyanobacteria (Lyngbya sp. 1 and Scytonema sp.) discriminated strongly between regions, and both were more abundant in the east. All other contributing species were most abundant in the west, with the excep- tion of Ceramium macilentum and Polysiphonia infestans which were most abundant in the north.

Few strong trends were apparent in the morphological form of those species that contributed strongly to dissimilarities among regions. The 2 consistent trends were for the articulated coralline algae (Matagonolithon stelliferum and the grouped Haliptilon/Jania spp.) to be more abundant in the western region, which is more exposed to ocean swells, and for the filamentous species to be more abundant in the other regions. However, many of the corticated filamentous and foliose algae showed no clear trend.

The SIMPER analyses do not indicate the most important source of spatial variation. The nested ANOVA (Table 7) showed that those species that displayed significant spatial patterns in Amphibolis griffithii tended to vary significantly at the site level. In total, 29 species showed significant spatial variability in winter and 31 in summer, amounting to $38 \%$ of the epiphyte species on both occasions. Of these, 20 (69\%) and $23(74 \%)$ species were variable at the site within region scale, respectively. In contrast, fewer species on Posidonia coriacea showed any significant spatial variation; $10(18 \%)$ in winter and 7 (16\%) in summer. Variation at the site level was again important, with 5 species showing variation at this scale on both occasions. In other words, more species (over one-third) were spatially variable in A. griffithii and of these, the majority were variable at the site scale. Far fewer species were spatially variable in $P$. coriacea (about one-sixth), though again variation at the site scale was important.

\section{DISCUSSION}

\section{Between-seagrass patterns}

The largest and most consistent source of variation in epiphyte species richness and composition was seagrass host. The higher species richness recorded on Amphibolis griffithii in our study is consistent with other studies. Between 66 and 150 species of epiphytic macroalgae were recorded on Amphibolis spp. by Ducker et al. (1977), Borowitzka et al. (1990), Kendrick et al. (1988) and Jernakoff \& Neilsen (1998); the lower value was from a study which included only stem epiphytes and had a low sampling effort compared to our study (Kendrick et al. 1988). These results support a trend for higher species richness on Amphibolis species. Leaf area indices (area of seagrass per unit area of habitat) for A. griffithii and Posidonia coriacea in our study area range from 3.4 to 18.0 and 1.9 to 3.5 , respectively (Kendrick et al. 1999). This raises the potential for uneven sampling effort when sampling on a unit area of habitat basis, as the area available for epiphyte 
Table 7. Summary of nested ANOVA testing for differences in proportion of shoots on which taxa occurred among regions and locations within regions for Amphibolis griffithii and Posidonia coriacea. ${ }^{*} \mathrm{p}<0.05 ;{ }^{* *} \mathrm{p}<0.01$; ns $=$ not significantly different; $\mathrm{v}=$ not tested due to heterogeneous variances; nd = no data (not present on that sampling occasion). Taxa that were either (v) and/or (nd) on both occasions are not included

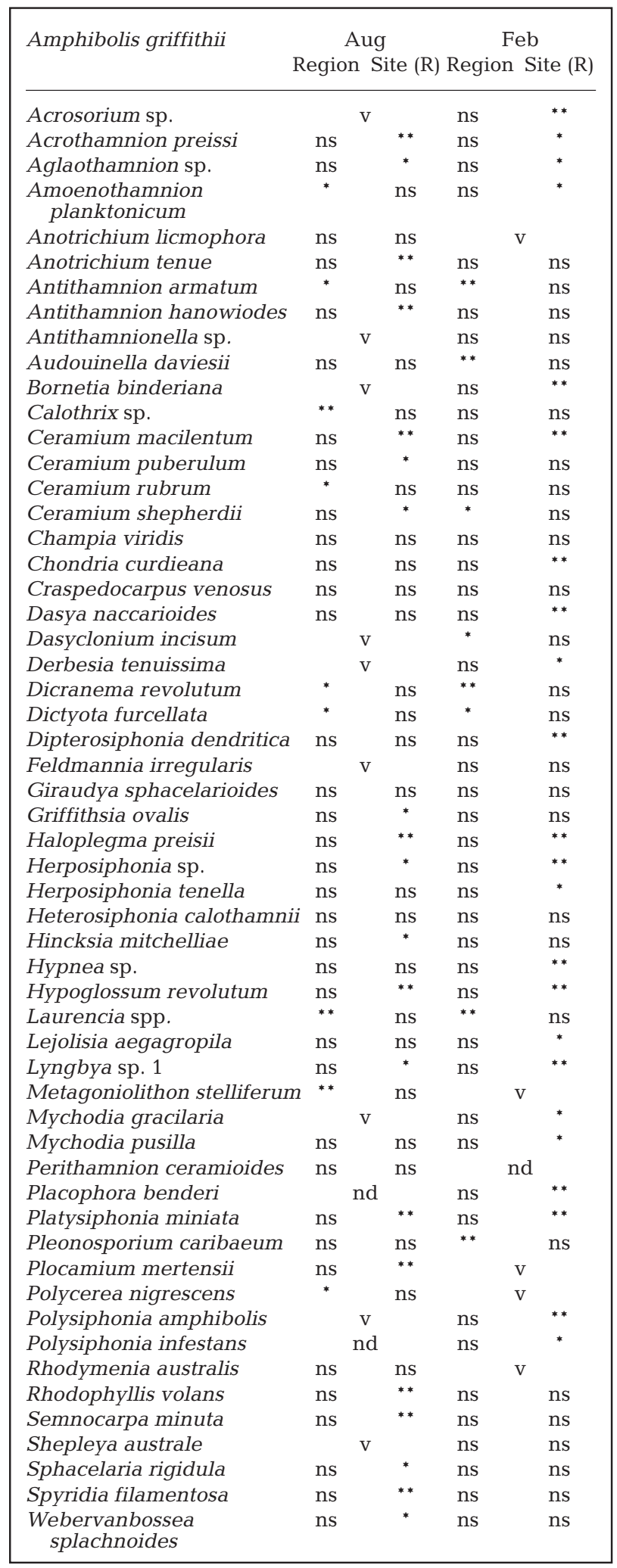

\begin{tabular}{|c|c|c|c|c|}
\hline Posidonia coriacea & $\begin{array}{r}A \\
\text { Region }\end{array}$ & $\begin{array}{l}\text { Aug } \\
\text { n Site (R) }\end{array}$ & $\begin{array}{r}\mathrm{F} \\
\text { Region }\end{array}$ & $\begin{array}{l}\text { Feb } \\
\text { on Site (R) }\end{array}$ \\
\hline Aglaothamnion sp. 1 & ns & ns & & nd \\
\hline $\begin{array}{l}\text { Amoenothamnion } \\
\text { planktonicum }\end{array}$ & ns & ns & & nd \\
\hline Anotrichium licmophora & ns & ns & ns & * \\
\hline Anotrichium tenue & & nd & ns & ns \\
\hline Antithamnion hanowiodes & ns & ns & & $\mathrm{v}$ \\
\hline Antithamnionella sp. & ns & ns & & $\mathrm{v}$ \\
\hline Audouinella daviesii & ns & $* *$ & ns & ns \\
\hline Ceramium macilentum & & $\mathrm{v}$ & ns & ns \\
\hline Ceramium puberulum & * & ns & & $\mathrm{V}$ \\
\hline Ceramium rubrum & ns & $*$ & & $\mathrm{v}$ \\
\hline Chondria curdieana & ns & ns & * & ** \\
\hline $\begin{array}{l}\text { Coralline algae spp. } \\
\text { (encrusting) }\end{array}$ & & $\mathrm{v}$ & ns & ns \\
\hline Dictyota furcellata & & nd & ** & ns \\
\hline Dipterosiphonia dendritica & ns & ns & & $\mathrm{v}$ \\
\hline Feldmannia irregularis & * & ns & & $\mathrm{v}$ \\
\hline Giraudya sphacelarioides & $* *$ & ns & ns & ns \\
\hline Griffithsia ovalis & * & ns & & $\mathrm{v}$ \\
\hline Haliptilon/Jania & ns & ns & & $\mathrm{v}$ \\
\hline Herposiphonia sp. & & $\mathrm{v}$ & ns & ns \\
\hline Heterosiphonia calothamnii & ii ns & ns & & nd \\
\hline Hincksia mitchelliae & ns & * & ns & * \\
\hline Hypnea sp. & ns & ns & ns & ns \\
\hline Lejolisia aegagropila & ns & ns & & nd \\
\hline Lyngbya sp. 1 & & $\mathrm{v}$ & ns & ns \\
\hline Platysiphonia miniata & ns & ns & ns & ns \\
\hline Polycerea nigrescens & $* *$ & ns & ns & $*$ \\
\hline Polysiphonia amphibolis & ns & $*$ & & $\mathrm{v}$ \\
\hline Polysiphonia infestans & & nd & ns & ns \\
\hline Scytonema sp. & & nd & $* *$ & ns \\
\hline Sphacelaria rigidula & ns & $* *$ & ns & ns \\
\hline Spyridia filamentosa & ns & ns & ns & * \\
\hline
\end{tabular}

colonisation is significantly different between seagrasses. In reality, however, this is unlikely to have a significant influence because the majority of epiphytic macroalgal biomass and species richness on A. griffithii is located on the stems. In our study, $87 \%$ of macroalgal biomass was on the stems with no epiphytic species unique to the leaves (although Herposiphonia spp. and Amoenothamnion planktonicum were disproportionately abundant on the leaves; pers. obs.). Similar observations have been made by others (Lethbridge et al. 1988, Borowitzka \& Lethbridge 1989, Jernakoff \& Neilsen 1998). We recorded mean stem and shoot densities of $301 \pm 20$ and $771 \pm 46$ for A. griffithii and $P$. coriacea, respectively (unpubl. data). These observations indicate that the major contribution to epiphyte biomass and species richness in A. griffithii is from the stems, which are numerically fewer and have a lower surface area per unit area than the leaves of 
P. coriacea. Even if leaves were removed from A. griffithii samples, the species richness of macroalgal epiphytes would remain much the same, and on a surface area much smaller than the seagrass surface available in a comparable patch of $P$. coriacea. The higher species richness of macroalgal epiphytes on A. griffithii is not, therefore, an artefact of sampling effort.

The low number of algal species found uniquely on Posidonia coriacea indicates that the assemblages on this seagrass were comprised of a sub-set of the taxa found on Amphibolis griffithii rather than being a fundamentally different assemblage. The species richness of $P$. coriacea is higher than that recorded for other Posidonia species, although still less than on species of Amphibolis. Cinelli et al. (1984) recorded 19 species of epiphytic macroalgae on $P$. oceanica, and $P$. sinuosa meadows in the vicinity of our study had 45 to 51 species (Kendrick \& Burt 1997, Jernakoff \& Neilsen 1998), most of which were found on $P$. coriacea in our study.

Differences in the species composition of epiphyte assemblages growing on different seagrasses have been noted in other studies (May \& Collins 1978, Borowitzka \& Lethbridge 1989, Jernakoff et al. 1996). The differences between the epiphyte assemblages on Amphibolis griffithii and Posidonia coriacea in our study are likely to be related to morphological and longevity differences between the seagrasses. A. griffithii has a long-lived, lignified stem with clusters of short-lived leaves at the apex, while $P$. coriacea has 'strap-shaped' leaves with no exposed stem or rhizome, so that all surfaces available for epiphyte colonisation are relatively short-lived. The leaf turnover time in $P$. coriacea is in the range of 35 to $128 \mathrm{~d}$ (Lavery et al. 1999), compared with over $700 \mathrm{~d}$ for the stems and 5 to $80 \mathrm{~d}$ for leaves of A. griffithii (Coupland 1997). Why certain species were present only on A. griffithii may be related, inter alia, to interactions between the longevity of the seagrass and the reproductive biology of the algae. Interactions between host longevity and epiphyte reproductive periodicity may also explain the differences in temporal and spatial patterns in epiphyte assemblages found on the 2 seagrasses, as will be discussed below.

\section{Comparison of spatial patterns}

Epiphyte assemblages on both Amphibolis griffithii and Posidonia coriacea displayed strong spatial patterns, with differences evident at scales of $100 \mathrm{~s} \mathrm{~m}$ and $\mathrm{km}$. However, there were differences between seagrasses in the magnitude of dissimilarities at different spatial scales. This suggests a fundamental difference in the way assemblages of epiphytic algae are formed and maintained on each seagrass, hinting at complex inter- actions among environmental factors that influence the structure of epiphyte assemblages and the biology of the seagrass host and the epiphytes themselves.

A variety of environmental factors have been shown or postulated as being responsible for patterns in epiphyte assemblages, either temporally or at a variety of spatial scales. These include hydrodynamics, light limitation, temperature, nutrient enrichment and salinity (Brouns \& Heijs 1986, Kendrick et al. 1988, Frankovich \& Fourqurean 1997, Kendrick \& Burt 1997, Schanz et al. 2000, Vanderklift \& Lavery 2000). It is possible that several of these environmental factors contribute to the spatial variability documented in this study. Burt et al. (1995) described a strong energy gradient across Success Bank. Lemmens et al. (1996) demonstrated a gradient in nutrient concentrations in the vicinity of our study region, and Anonymous (1996) described a seasonal input of nutrients from the nearby Swan River estuary. Both these gradients (energy and nutrients) could influence epiphyte assemblages across Success Bank. Kendrick \& Burt (1997) ascribed some of the spatial patterns in Posidonia sinuosa epiphytes to the energy gradient, implying that coralline algae have a competitive advantage over filamentous algae at the more exposed, westernmost sites. Conversely, filamentous algae may be more competitive at the easternmost sites, which are closer to land-based sources of nutrients. We observed a similar trend with articulated coralline algae contributing significantly to regional differences in composition of assemblages, being most abundant in the western region on both Amphibolis griffithii and P. coriacea. Several species of finer, filamentous algae were more abundant in the east or north regions. Many other species of filamentous algae showed no clear differences in abundance between regions, and 1 (Acrothamnion preisii) was more abundant in the west, suggesting that any interaction of energy gradients and algal morphology is not a simple one. We observed highly significant differences in the abundance of some cyanophyta in the east, closer to the major sources of land-derived nutrients. Elsewhere the occurrence of cyanobacterial species has been attributed to seasonal influxes of nutrients (Humm 1964, Heijs 1987).

While environmental gradients may account for some of the spatial variability, we noted at the $\mathrm{km}$ scale, many species showed no significant differences in abundance between regions, but varied at scales of $100 \mathrm{~s} \mathrm{~m}$. If environmental factors alone were driving the patterns in epiphyte assemblages, then we would expect comparable or greater variability at the regional scale, and we would also expect similar patterns in dissimilarity at different spatial scales for assemblages on Amphibolis griffithii and Posidonia coriacea. The fact that different patterns in dissimilarity were 
observed for the 2 seagrasses suggests that some other, biological, process is important. Grazing may influence abundance and diversity of epiphytic algae. Alcoverro et al. (1997) showed that spatial variations in epiphyte biomass were partly due to herbivory and Lotze et al. (2000) and Hall \& Bell (1988) have demonstrated that complex interactions between grazers, nutrient availability, propagule banks and other factors can influence macroalgal composition. While grazing may contribute to patterns in epiphyte assemblages, we propose that herbivory may be a less important biological process here than the interactions between seagrass longevity and propagule dispersal. We propose that inter-specific differences in seagrass longevity and how this interacts with algal reproductive biology are more important in producing the different spatial patterns of dissimilarity for the 2 seagrasses on Success Bank.

For most algae, little is known about the dispersal ranges of propagules. Most of those that have been studied have small propagule dispersal shadows, in the order of m (Hoffman 1987, Santelices 1990, Kendrick \& Walker 1991, Serrão et al. 1997), although there is indirect evidence of dispersal shadows up to $\mathrm{km}$ for a few chlorophyte species (Zechman \& Mathieson 1985, Reed et al. 1988). As the majority of epiphyte species found in this study were rhodophytes, the dispersal range for most of the species in the assemblages is probably $10 \mathrm{~s}$ $\mathrm{m}$. We can therefore expect at least 3 different scales of recruitment to influence the composition of epiphyte assemblages on a stem or leaf: within-patch recruitment from algae on adjacent stems and leaves, localscale recruitment from reefs and other sources within the dominant algal propagule dispersal range (probably $10 \mathrm{~s}$ to $100 \mathrm{~s} \mathrm{~m}$ ), and large-scale recruitment due to oceanic currents and other processes ( $\mathrm{km}$ and greater). All 3 processes would introduce algal recruits to seagrass patches in our study site, although Hoffman (1987) suggests that the largest spatial scale of recruitment is likely to be less important. We hypothesise that the different patterns of dissimilarity with respect to spatial scales in the 2 species of seagrass is due to differences in the relative importance of within-patch and local-scale recruitment. In Amphibolis griffithii ecosystems, where stems persist for long periods (about 2 yr), we would expect the majority of algal thalli to persist long enough to reproduce. In this case, we expect that the existing assemblage strongly influences the nature of future assemblages in the immediate patch $(\mathrm{m}$ to $10 \mathrm{~s} \mathrm{~m}$ ) through localised dispersal, creating a reinforcement of the pre-existing assemblage. This is consistent with the relatively large percentage of epiphytic taxa on A. griffithii showing spatial variability at small spatial scales (our site scale). In Posidonia coriacea ecosystems, where leaf turnover rate is faster, a larger proportion of algal thalli may not reach reproductive maturity, or may reproduce less often, before the leaf is shed. In this case, reinforcement of assemblage structure from within the patch may be weaker, and recruitment from the local area (such as nearby reefs) may have a comparatively stronger influence on assemblage structure, producing greater homogeneity at that scale. Such mechanisms would lead to strong patchiness in assemblages growing on A. griffithii, and weaker patchiness in assemblages growing on $P$. coriacea. Examination of patterns in assemblages on $A$. griffithii leaves or mixed meadows of the 2 seagrasses was not conducted as part of this study, but could be useful tests of our hypothesis. If our hypothesis is correct, macroalgal assemblages on leaves of $A$. griffithii, which have faster turnover rates than the leaves of $P$. coriacea, should display similar spatial patterns in dissimilarity to $P$. coriacea, and mixed stands of the seagrasses might be expected to show intermediate patterns.

At larger spatial scales, assemblage structure is likely to be affected by other processes (e.g. coastal currents or energy gradients), so more significant dissimilarities in assemblage structure would exist. This model is consistent with the observation that while relatively few epiphytes on Posidonia coriacea showed significant differences in abundance at small spatial scales (100s m-our site scale), there were large differences in abundance among regions, where environmental influences are likely to be most significant. This model also accounts for a consistent increase in dissimilarity of epiphyte assemblages with increasing spatial scale for Amphibolis griffithii, but for a saltatory change in dissimilarity in $P$. coriacea ecosystems, with most change occurring at the larger spatial scales.

\section{Comparison of temporal patterns in assemblages}

Posidonia coriacea epiphyte assemblages displayed strong differences between times of sampling. We cannot verify whether these are seasonal or shorter-term patterns, or whether they are consistent between years or relatively random temporal patterns. However, similar temporal variability has been recorded for other seagrass species (Cinelli et al. 1984, Kendrick \& Burt 1997, Reyes \& Sansón 1997). We observed a similar, but less dramatic, shift for Amphibolis griffithii assemblages, consistent with observations of Borowitzka et al. (1990). Kendrick \& Burt (1997) showed this for $P$. sinuosa sampled nearby, but also found that the patterns of seasonality varied between sites. They related these patterns to a variety of factors, including seasonality of leaf longevity and grazing pressures. Others have related temporal patterns in epiphytic macroalgal assemblages to various combinations of leaf longevity, 
periodicity of algal propagation, environmental factors, substrate damage, grazing and the physicochemical nature of the substrate (Jacobs et al. 1983, Borum 1985, Heijs 1987, Lethbridge et al. 1988, Alcoverro et al. 1997).

It is possible that the relatively short turnover time of leaves in Posidonia coriacea also accounts for the more dramatic temporal shift in assemblage composition than occurs in Amphibolis griffithii. A rapid host-leaf turnover time has the potential to interact with similar or short-term algal recruitment events to produce distinct temporal differences. If host-leaf turnover rates are shorter than, or comparable to, those of key algal recruitment events, then there is the potential for cohorts of leaves to 'miss' a recruitment episode, potentially leading to a distinct temporal difference in algal assemblages. For example, if an algal population recruits in 1 or a few synchronous events (say an autumn reproductive species), but the host leaves are shed before the juvenile algal population reaches reproductive age, then that species will only be present in the meadow for a short period of time. If a large number of algae suffer this fate, then an epiphyte assemblage would show quite marked differences in composition at time scales greater than the leaf turnover time scale (for example, seasonal time scales). Reyes \& Sansón (1997) showed that about $50 \%$ of algal epiphytes on Cymodocea nodosa were not reproductive during their $1 \mathrm{yr}$ study, and of the $50 \%$ which were, half of them were seasonally reproductive. Assuming similar characteristics among the algal epiphytes of $P$. coriacea, a 35 to $128 \mathrm{~d}$ turnover rate could well result in some cohorts of leaves completing their entire life cycle more rapidly than a single reproductive event in some potential algal epiphytes, and possibly producing a strong temporal pattern in epiphyte assemblages. A. griffithii stems on the other hand have a very slow turnover rate and most epiphyte biomass is on the perennial stems; therefore, even those species with reproductive cycles in excess of $1 \mathrm{yr}$ should have the opportunity to recruit. The stem assemblage will therefore reflect the pre- and postrecruitment processes acting over a relatively long time scale and this is likely to dampen, but not remove, any strong recruitment signal occurring at shorter time scales, such as seasonal.

\section{CONCLUSIONS}

We conclude that temporal and spatial patterns in the assemblages of epiphytic macroalgae growing on Amphibolis griffithii and Posidonia coriacea are significantly different. We propose that these differences result from complex interactions between the time scales of host longevity and algal reproduction and the spatial scale of propagule dispersal. Environmental gradients also influence spatial and temporal patterns in these assemblages, but we suspect that these are likely to be more consistent in their effects over both seagrass types.

So what then are the implications of these spatial patterns for the functioning of seagrass ecosystems? Differences in species composition and abundance of individual taxa in assemblages of macroalgal epiphytes growing on Amphibolis griffithii and Posidonia coriacea and their spatial and temporal variability may influence the magnitude, timing and spatial locations of the ecological functions epiphytes perform, such as primary productivity, nutrient cycling, provision of a food source to grazers and contribution to diversity. As the contribution of epiphytes to these functions in seagrass ecosystem can be significant, it is possible that many of the functions of seagrass ecosystems will also vary in space and time. The nature of this variability will be related to the different processes that interact to create complex many layered patterns in the structure of epiphytic macroalgal assemblages. At the large scale $(\mathrm{km})$, we have large differences in assemblages that are likely to reflect environmental gradients. At the next scale $(100 \mathrm{~s} \mathrm{~m})$ a different set of processes have effect, giving patchiness within gradients. In the case of A. griffithii and P. coriacea ecosystems, we propose that this smaller-scale patchiness differs due to the influences of seagrass longevity, reproductive periodicity in algae and spatial extent of dispersal.

This study was based on a survey of seagrass ecosystems at 6 locations within 3 regions. It is unavoidable that a single data set of this sort will have limitations: for example, while spatially intensive our temporal replication was limited to 2 dates. In addition, the paucity of information on algal propagule dispersal and frequency of reproduction requires us to hypothesise about possible interactions between seagrass and algal biology. However, comprehensive data sets of algal distribution and site-specific occurrences covering a regional scale are uncommon, and especially so for seagrass epiphytes. Therefore, the analysis and hypotheses we have presented here serve as a starting point to examine patterns and processes in seagrass, and hopefully will encourage further studies, either empirical or through numerical modelling, which will further explore assemblage structure and function at larger spatial scales.

Acknowledgements. We are grateful to Dr. John Huisman for confirming the identity of many of our epiphyte species, and to Mark Westera for his assistance with fieldwork. Thanks to Prof. Lena Kautsky and Drs. Kari Lehtilä, Gunnar Austrheim and Gary Kendrick for comments on the manuscript. We gratefully acknowledge the support of Profs. Di Walker and Des Lord in arguing the need for this research and Cockburn Cement Ltd who funded the project. 


\section{LITERATURE CITED}

Alcoverro T, Duarte CM, Romero J (1997) The influence of herbivores on Posidonia oceanica epiphytes. Aquat Bot 56: 93-104

Anonymous (1996) Southern metropolitan coastal waters study 1991-1994, Final Report. Report 17, Department of Environmental Protection, Perth, Western Australia, p 288

Arrontes J (1990) Composition, distribution on host, and seasonality of epiphytes on three intertidal algae. Bot Mar 33: 205-211

Ballantine DL (1979) The distribution of algal epiphytes on macrophyte hosts offshore from La Parguera, Puerto Rico. Bot Mar 22:107-111

Belbin L (1991) Semi-strong hybrid scaling, a new ordination algorithm. J Veg Sci 2:491-496

Belbin L (1993) PATN Pattern Analysis Package: user's guide. CSIRO Division of Wildlife and Ecology, Australia, p 79

Borowitzka MA, Lethbridge RC (1989) Seagrass epiphytes. In: Larkum AWD, McComb AJ, Shepherd SA (eds) Seagrasses: a treatise on seagrasses with special reference to the Australian region. Elsevier Science Publishers, Amsterdam, p 304-345

Borowitzka MA, Lethbridge RC, Charlton L (1990) Species richness, spatial distribution and colonisation pattern of algal and invertebrate epiphytes on the seagrass Amphibolis griffithii. Mar Ecol Prog Ser 64:281-291

Borum J (1985) Development of epiphytic communities on eelgrass Zostera marina along a nutrient gradient in a Danish estuary. Mar Biol 87:211-218

Bray JR, Curtis JT (1957) An ordination of the upland forest communities of southern Wisconsin. Ecol Monogr 27: 325-349

Brouns JJWM, Heijs FML (1986) Production and biomass of the seagrass Enhalus acoroides L. f. Royle and its epiphytes. Aquat Bot 25:21-45

Buia MC, Cormaci M, Furnari G, Mazzella L (1989) Posidonia oceanica off Capo Passero Sicily, Italy: leaf algal epiphytic community. In: Boudouresque $\mathrm{CF}$, Meinesz A, Fresi E, Gravez V (eds) International workshop on Posidonia beds. GIS Posidonie, Porquerolles, France, p 127-143

Bulthuis DA, Woelkerling WJ (1983) Biomass accumulation and shading effects of epiphytes on the leaves of the seagrass Heterozostera tasmanica in Victoria, Australia. Aquat Bot 16:137-148

Burt JS, Masini RJ, Simpson CJ (1995) Light and Posidonia sinuosa seagrass meadows in the temperate coastal waters of Western Australia: I. Factors influencing water column light attenuation. Technical Series 6, December 1995. Environmental Protection Authority, Perth, Western Australia

Cambridge ML, Chiffings AW, Brittan C, Moore L, McComb AJ (1986) The loss of seagrass in Cockburn Sound, Western Australia. II. Possible causes of seagrass decline. Aquat Bot 24:269-285

Carr MR (1997) PRIMER User manual. Plymouth routines in multivariate ecological research. Plymouth Marine Laboratory, Plymouth

Cary JL, Masini RJ, Simpson CJ (1995) The water quality of the southern metropolitan coastal waters of Perth, Western Australia: The influence of regional and local scale forcings. Technical Series 64, November 1995. Department of Environmental Protection, Perth, Western Australia

Cebrián JS, Enríquez S, Fotes M, Agawin N, Vermaat JE, Duarte CM (1999) Epiphyte accrual on Posidonia oceanica L. Delile leaves: implications for light absorption. Bot Mar 42:123-128
Cinelli F, Cormaci M, Furnari G, Mazzella L (1984) Epiphytic macroflora of Posidonia oceanica L. Delile leaves around the island of Ischia Gulf of Naples. International workshop on Posidonia oceanica beds. GIS Posidonie, Porquerolles, France

Clarke KR (1993) Non-parametric multivariate analyses of change in community structure. Aust J Ecol 18:117-143

Coleman VL, Burkholder JM (1994) Community structure and productivity of epiphytic microalgae on eelgrass Zostera marina L. under water-column nitrate enrichment. J Exp Mar Biol Ecol 179:29-48

Coupland G (1997) Rhizome and shoot structure, growth and response to sediment burial in Amphibolis griffithii (Black) den Hartog. Honours thesis, University of Western Australia

Cullinane JJ, Mahoney O, Whelan P (1985) Algal epiphytes of subtidal Zostera marina L. on the south coast of Ireland. Cryptogam Algol 6:239-251

D'Adamo N, Mills DA, Wilkinson DL (1995) Winter mixing and transport in the stratified coastal embayment of Cockburn Sound, Western Australia. Technical Series 70, December 1995. Environmental Protection Authority, Perth, Western Australia

Ducker SC, Foord NJ, Knox RB (1977) Biology of Australian seagrasses: the genus Amphibolis C. Agardh. Cymodoceacea. Aust J Bot 25:67-95

Frankovich TA, Fourqurean JW (1997) Seagrass epiphyte loads along a nutrient availability gradient, Florida Bay, USA. Mar Ecol Prog Ser 159:37-50

Hall MO, Bell SS (1988) Response of small motile epifauna to complexity of epiphytic algae on seagrass blades. J Mar Res 46:613-630

Heijs FML (1987) Qualitative and quantitative aspects of the epiphytic component in a mixed seagrass meadow from Papua New Guinea. Aquat Bot 27:363-383

Hoffmann AJ (1987) The arrival of seaweed propagules at the shore: a review. Bot Mar 30:151-165

Humm HJ (1964) Epiphytes of the sea grass, Thalassia testudinum, in Florida. Bull Mar Sci Gulf Caribb 14:306-341

Jacobs RPWM, Hermelink PM, Van Geel G (1983) Epiphytic algae on eelgrass at Roscoff, France. Aquat Bot 15:157-173

Jernakoff P, Nielsen J (1998) Plant-animal associates in two species of seagrasses in Western Australia. Aquat Bot 60: 359-376

Jernakoff P, Brearley A, Nielsen J (1996) Factors affecting grazer-epiphyte interactions in temperate seagrass meadows. Oceanogr Mar Biol Annu Rev 34:109-162

Kendrick GA, Burt JS (1997) Seasonal changes in epiphytic macro-algae assemblages between offshore exposed and inshore protected Posidonia sinuosa Cambridge et Kuo seagrass meadows, Western Australia. Bot Mar 40:77-85

Kendrick GA, Walker DI (1991) Dispersal distances for propagules of Sargassum spinuligerum (Sargassaceae, Phaeophyta) measured directly by vital staining and venturi suction sampling. Mar Ecol Prog Ser 79:133-138

Kendrick GA, Walker DI, McComb AJ (1988) Changes in distribution of macro-algal epiphytes on stems of the seagrass Amphibolis anatarctica along a salinity gradient in Shark Bay, Western Australia. Phycologia 27:201-208

Kendrick GA, Huisman JM, Walker DI (1990) Benthic macroalgae of Shark Bay, Western Australia. Bot Mar 33:47-54

Kendrick GA, Eckersley J, Walker DI (1999) Landscape-scale changes in seagrass distribution over time: a case study from Success Bank, Western Australia. Aquat Bot 65: 293-309

Lavery P, Westera M, Kendrick G, Brearley A, Campey M, Hegge B, Hillman K (1999) Shellsand Dredging Environmental Management Programme, Project S1: Ecological 
significance of seagrasses. Calcium carbonate and nitrogen turnover on Success Bank, Owen Anchorage, Phase 3 report. D A Lord and Associates, Nedlands, Western Australia

Lemmens JWTJ, Clapin G, Lavery P, Cary J (1996) Filtering capacity of seagrass meadows and other habitats of Cockburn Sound, Western Australia. Mar Ecol Prog Ser 143: $187-200$

Lethbridge RC, Borowitzka MA, Benjamin KJ (1988) The development of an artificial, Amphibolis-like seagrass of complex morphology and preliminary data on its colonization by epiphytes. Aquat Bot 31:153-168

Lotze HK, Worm B, Sommer U (2000) Propagule banks, herbivory and nutrient supply control population development and dominance patterns in macroalgal blooms. Oikos 89:46-58

May V, Collins AJ (1978) A comparative study of epiphytic algal communities on two common genera of sea-grasses in eastern Australia. Aust J Ecol 3:91-104

Moncreiff CA, Sullivan MJ, Daehnick AE (1992) Primary production dynamics in seagrass beds of Mississippi Sound: the contributions of seagrass, epipihytic algae, sand microflora and phytoplankton. Mar Ecol Prog Ser 87: 161-171

Morgan MD, Kitting CL (1984) Production and utilization of the seagrass Halodule wrightii and its attached epipihytes. Limnol Oceanogr 29:1066-1076

Penhale PA (1977) Macrophyte-epiphyte biomass and productivity in an eelgrass Zostera marina L. community. J Exp Mar Biol Ecol 26:211-224

Pinckney JL, Micheli F (1998) Microalgae on seagrass mimics: does epiphyte community structure differ from live seagrasses? J Exp Mar Biol Ecol 221:59-70

Reed DC, Laur DR, Ebeling AW (1988) Variation in algal dispersal and recruitment: the importance of episodic events. Ecol Monogr 58:321-335

Reyes J, Sansón M (1997) Temporal distribution and reproductive phenology of the epiphytes on Cymodocea nodosa leaves in the Canary Islands. Bot Mar 40:193-201

Editorial responsibility: Kenneth Heck (Contributing Editor), Dauphin Island, Alabama, USA
Rogers MP (1996) Owen Anchorage near-bed wave induced orbital currents study. Report to Cockburn Cement Ltd by MP Rogers \& Associates Pty Ltd, Osborne Park, Western Australia, Report R022

Rogers MP (1997) Owen Anchorage Wave Study. Effects of the proposed medium term dredging. Report to Cockburn Cement Ltd by MP Rogers \& Associates Pty Ltd, Osborne Park, Western Australia, Report R025

Sand-Jensen KJ (1977) Effect of epiphytes on eelgrass photosynthesis. Aquat Bot 3:55-63

Santelices B (1990) Patterns of reproduction, dispersal and recruitment in seaweeds. Oceanogr Mar Biol Annu Rev 28:177-276

Schanz A, Polte P, Asmus H, Asmus R (2000) Currents and turbulence as top-down regulators in intertidal seagrass communities. Biol Mar Medit 7:278-281

Serrão EA, Kautsky L, Lifvergren T, Brawley SH (1997) Gamete dispersal and pre-recruitment mortality in Baltic Fucus vesiculosus. Abstracts of the 6th International Phycological Congress, 1997. Phycologia (Suppl) 36:101-102

Silberstein K, Chiffings AW, McComb AJ (1986) The loss of seagrass in Cockburn Sound, Western Australia. III. The effect of epiphytes on productivity of Posidonia australis Hook f. Aquat Bot 24:355-371

Vanderklift MA, Lavery PS (2000) Patchiness in assemblages of epiphytic macroalgae on Posidonia coriacea at a hierarchy of spatial scales. Mar Ecol Prog Ser 192:127-135

Vanderklift MA, Ward TJ, Jacoby CA (1996) Effect of reducing taxonomic resolution on ordinations to detect pollution-induced gradients in macrobenthic infaunal assemblages. Mar Ecol Prog Ser 136:137-145

Warwick RM, Platt HM, Clarke RK, Agard J, Gobin J (1990) Analysis of macrobenthic and meiobenthic community structure in relation to pollution and disturbances in Hamilton Harbour, Bermuda. J Exp Mar Biol Ecol 138: $119-142$

Zechman FW, Mathieson AC (1985) The distribution of seaweed propagules in estuarine, coastal offshore water of New Hamphire, USA Bot Mar 28:283-294

Submitted: February 19, 2001; Accepted: October 22, 2001 Proofs received from author(s): May 28, 2002 